\title{
UPAYA GURU PAI DALAM MEMBENTUK KARAKTER RELIGIUS MELALUI KEGIATAN KEAGAMAAN DI SMP MUHAMMADIYAH KARANGASEM BALI
}

\section{Abstrak:}

Bangsa yang memiliki karakter yang kuat akan menjadikan dirinya sebagai bangsa yang bermartabat.tetapi kondisi bangsa ini yang semakin menunjukkan perilaku anti budaya dan anti karakter dan mengalami krisis moral seperti praktik korupsi, kolusi, dan nepotisme yang semakin marak pada lembaga pemerintahan Fenomena di atas jelas mendapatkan kritikan terutama dalam dunia pendidikan, karena dunia pendidikan kita saat ini dinilai lebih memperhatikan aspek kognitif semata dari pertumbuhan kesadaran nilai-nilai (agama) dan mengabaikan pembinaan aspek afektif dan konatif volatif, yakni kemauan dan tekad untuk mengamalkan nilai-nilai ajaran agama. Akibatnya terjadi kesenjangan antara pengetahuan dan pengalaman, antara gnosis dan praxis dalam kehidupan nilai agama. Atau dalam praktik pendidikan agama berubah menjadi pengajaran agama, sehingga tidak mampu membentuk pribadi-pribadi bermoral, padahal inti dari pendidikan agama adalah pendidikan moral. Kalau kita simak pendidikan atau mendidik tidak hanya sebatas mentransfer ilmu saja, namun lebih jauh pengertian itu yang lebih utama adalah dapat mengubah dalam tataran etika maupun estetika dalam kehidupan sehari-hari. Dalam riset kali ini akan dikaji pembentukan karakter religious disebuah sekolah umum yang berafisiliasi organisasi keagamaan di Karang Asem Bali

Keyword: Pendidikan Karakter, Religius, Korupsi, Kolusi, Nepotisme

Asmuki

Dosen Fak. Tarbiyah IAI Ibrahimy Sukorejo Situbondo Asmukimadura@gmail.com 


\section{A. Konteks Penelitian}

Eksistensi suatu bangsa sangat ditentukan oleh karakter yang dimiliki oleh bangsa tersebut. Bangsa yang memiliki karakter yang kuat akan menjadikan dirinya sebagai bangsa yang bermartabat. Sudah hampir lima tahun (sejak tahun 2010) pemerintah Indonesia mencanangkan pembangunan budaya dan karakter bangsa yang diawali dengan dideklarasikannya "Pendidikan Budaya dan Karakter Bangsa" sebagai Gerakan Nasional Januari 2010. Pencanangan ini ditegaskan kembali dalam pidato Prsesiden pada peringatan Hari Pendidikan Nasional 2 Mei 2010. Sejak inilah pendidikan karakter menjadi perbincangan di tingkat nasional hingga saat ini, terutama bagi yang peduli dengan masalah pendidikan.

Deklarasi nasional tersebut tidak dapat dipungkiri oleh sebab kondisi bangsa ini yang semakin menunjukkan perilaku anti budaya dan anti karakter dan mengalami krisis moral seperti praktik korupsi, kolusi, dan nepotisme yang semakin marak pada lembaga pemerintahan. Perilaku seks bebas di kalangan generasi muda, penyalahgunaan narkoba, dan kenakalan remaja di manamana.

Menurut Zakiah Daradjat, kemerosotan akhlak (perilaku) disebabkan oleh kurang tertanamnya jiwa agama pada seseorang dan tidak terlaksananya pendidikan agama sebagaimana mestinya di keluarga, sekolah, dan masyarakat. ${ }^{1}$ Sedangkan saat ini tugas dan tanggung jawab pendidikan agama dan keluarga cenderung mempercayakan sebagian tanggung jawabnya kepada guru PAI. Agama merupakan acuan utama yang membawa meraka untuk membentuk kehidupan yang bermoral. $^{2}$ Mengingat betapa pentingnya pendidikan agama karena sangat berpengaruh pada karakter peserta didik.

\footnotetext{
${ }^{1}$ Zakiah Daradjat, Ilmu Jiwa Agama, (Jakarta: Bumi Aksara, 1992), Cet. 11, h. 49

2 Thomas Lickona, Educating For Character: Mendidik Untuk Membentuk Karakter, (Jakarta: PT Bumi Aksara, 2013) h. 64
} 
Salah satu lembaga pendidikan Sekolah Menengah Pertama (SMP) Muhammadiyah yang peduli terhadap pembinaan karakter seperti membiasakan siswa membersihkan lingkungan sekolah, disiplin dengan peraturan yang ada di sekolah, bimbingan dan keteladanan yang diterapkan oleh guru melalui kegiatan keagamaan. Di antara pembinaan karakter tersebut yang paling menonjol di SMP Muhammadiyah adalah kegiatan keagamaan. Kegiatan keagamaan di SMP Muhammadiyah dibagi menjadi dua bentuk, yang pertama dalam bentuk pembelajaran seperti baca tulis Al Qur'an dan praktik kegiatan Pendidikan Agama Islam (PAI). Kedua dalam bentuk kegiatan yaitu shalat dhuha, membaca surah Al Waqi'ah bersama, Dzuhur berjamaah, dan ektrakurikuler keagamaan. Sehingga SMP Muhammadiyah dapat memiliki banyak prestasi dalam bidang keagamaan. Dari beberapa rangkaian kegiatan keagamaan yang sudah dilaksanakan di SMP Muhammadiyah Karangasem Bali dapat memberikan manfaat bagi perkembangan intelektual maupun emosionalnya. ${ }^{3}$

Salah satu kunci keberhasilan program pengembangan karakter pada satuan pendidikan adalah keteladanan dan pembiasaan dari para pendidik dan tenaga kependidikan. Keteladanan bukan sekedar sebagai contoh bagi peserta didik, melainkan juga sebagai penguat moral bagi peserta didik di dalam bersikap dan berperilaku. Oleh karena itu, penerapan keteladanan di lingkungan satuan pendidikan menjadi prasyarat dalam pengembangan karakter peserta didik. ${ }^{4}$ Dari konteks penelitian di atas, peneliti tertarik untuk melakukan Riset dengan judul "Upaya Guru PAI dalam Membentuk Karakter Religius Melalui Kegiatan Keagamaan di SMP Muhammadiyah Karangasem Bali”.

Berdasarkan konteks penelitian yang telah dipaparkan di atas, maka fokus penelitian ini adalah sebagai berikut :

\footnotetext{
${ }^{3}$ Wawancara dengan Bapak Mafrul Suhaedi, S.Pd.I. Pada Tanggal 21 Maret 2015

${ }^{4}$ Pupuh Fathurrohman, dkk, Pengembangan Pendidikan Karakter, (Bandung: PT Refika Aditama, 2013) h. 47
} 
1. Bagaimana upaya guru PAI dalam membentuk karakter religius melalui kegiatan keagamaan di SMP Muhammadiyah Karangasem Bali ?

2. Apa faktor-faktor pendukung dan penghambat dalam melaksanakan pembentukan karakter religius melalui kegiatankegiatan keagamaan di SMP Muhammadiyah Karangasem Bali ?

3. Bagaimana hasil pembentukan karakter religius melalui kegiatan keagamaan di SMP Muhammadiyah Karangasem Bali ?

\section{B. Metode Penelitian}

Dalam riset ini, peneliti menggunakan pendekatan kualitatif yang artinya jenis riset yang temuan-temuannya tidak diperoleh melalui prosedur statistik atau bentuk hitungan lainnya. Riset kualitatif tidaklah menolak secara mutlak terhadap angka dan kepentingan tetapi angka dan perhitungan dapat digunakan jika membantu pemahaman dan penjelasannya namun tetap dalam kerangka kualitatif. ${ }^{5}$

Riset kualitatif menurut Bogdan dan Taylor, sebagaimana dikutip oleh Meleong adalah sebagai prosedur riset yang menghasilkan data deskriptif berupa kata-kata tertulis atau lisan dari orang-orang dan pelaku yang dapat diamati. ${ }^{6}$

Peneliti dalam riset ini menggunakan jenis riset dengan studi kasus. Studi kasus adalah suatu riset yang mendeskripsikan dan menganalisis secara intensif, terinci dan mendetail terhadap suatu organisasi lembaga dan gejala tertentu. Dalam artian riset difokuskan pada suatu fenomena yang dipilih dan ingin dipahami secara mendalam dengan mengabaikan fenomena-fenomena lainnya. $^{7}$

\footnotetext{
${ }^{5}$ Nusa Putra dan Nanin Dwi Lastri, Penelitian Kualitatif PAUD, (Jakarta: PT. Raja Grafindo Persada, 2012), Cet. ke-2, h. 66

${ }^{6}$ Lexy J. Meleong, Metode Penelitian Kualitatif, (Bandung: PT. Remaja Rosda karya, 2014) h. 4

${ }^{7}$ Nana Syaodih Sukmadinata, Metode Penelitian Pendidikan, ( Bandung: PT Remaja Rosda Karya, 2010), h. 60
} 
Sedangkan pengumpulan data tergantung pada jenis dan sumber data yang diperlukan. Pada umumnya pengumpulan data dapat dilakukan dengan beberapa metode, baik yang bersifat alternatif maupun kumulatif yang saling melengkapi. ${ }^{8}$

Sumber data utama dalam riset kualitatif adalah kata-kata dan tingkah laku (tindakan) selebihnya adalah tambahan seperti dokumen dan lain-lain. Dan pengumpulan datanya dilakukan secara langsung. Dalam hal ini, peneliti menggunakan metode observasi, interview dan dokumentasi.

1. Observasi

Observasi diartikan sebagai pengamatan dan pencatatan secara sistematik terhadap gejala yang tampak pada objek riset. ${ }^{9}$

Data yang hendak diperoleh riset dari observasi dalam riset ini adalah :

a. Situasi dari kondisi objek riset.

b. Proses kegiatan keagamaan di SMP Muhammadiyah Karangasem Bali.

c. Proses pembelajaran (praktik PAI) di SMP Muhammadiyah Karangasem Bali

Sedangkan prosedur pelaksanaan dalam observasi ini adalah:

a. Mengadakan peninjauan lokasi yang akan digunakan sebagai tempat observasi

b. Menyusun pedoman observasi yang sesuai dengan masalah yang akan digunakan sebagai acuan dalam proses riset

c. Mengadakan observasi secara langsung terhadap peristiwa objek riset serta mencatat hasil yang telah diperoleh.

d. Mengklasifikasikan hasil observasi sesuai dengan focus riset.

${ }^{8}$ Cik Hasan Basri Ms, Penuntun Penyusunan Penelitian dan Penulisan Rencana Skripsi. (Jakarta: PT Logo Wacana Ilmu, 1998), Cet. ke-II, h. 60

${ }^{9}$ S. Margono, Metodologi Penelitian Pendidikan. (Jakarta : PT. Rineka Cipta, 1997), h. 158 
2. Interview

Metode interview atau wawancara adalah metode pengumpulan data dengan mengajukan pertanyaan secara lisan kepada subjek yang diteliti. ${ }^{10}$

Teknik ini digunakan untuk mengetahui secara mendalam, mendetail atau intensif terhadap pengalaman-pengalaman informal dari topik tertentu atau situasi spesifik yang dikaji. Oleh karena itu, dalam pelaksanaan wawancara atau interview peneliti gunakan pertanyaan-pertanyaan yang memerlukan jawaban berupa informasi. Sebelum memulai wawancara pertanyaan disiapkan terlebih dahulu (berupa pedoman wawancara) sesuai dengan jenis penggalian data yang diperlukan dan kepada siapa wawancara dilakukan.

Dalam melakukan riset, peneliti mendatangi para informan antara lain: kepala sekolah, wakil kepala sekolah, waka kurikulum, guru PAI dan siswa-siswi SMP Muhammadiyah Karangasem Bali untuk memperoleh keterangan rinci tentang substansi yang diwawancarakan mengenai upaya guru PAI dalam membentuk karakter religius melalui kegiatan keagamaan di SMP Muhammadiyah Karangasem Bali. Disamping pertanyaan-pertanyaan diatas, kadang-kadang peneliti menyelipkan pertanyaan pengalaman yang menjelaskan secara bebas dan rinci mengenai pandangan motivasi, prilaku dan aktifitas tentang "kegiatan keagamaan".

3. Dokumentasi

Di samping metode observasi dan wawancara atau interview, Peneliti ini juga menggunakan metode dokumentasi ini digunakan untuk melengkapi data yang diperoleh dari observasi dan wawancara.

Dokumentasi adalah catatan tertulis tentang berbagai kegiatan atau peristiwa yang lalu. Dokumentasi yaitu metode

${ }^{10}$ Wijaya Kusuma dan Dadi Dwitajama, Mengenal Penelitian Tindakan Kelas, (Jakarta : Indeks, 2009) h. 77 
dalam sebuah riset khususnya dalam pengumpulan data. Data yang dikumpulkan seperti data informasi-informasi dan keterangan-keterangan yang diperlukan. ${ }^{11}$

Dalam metode ini, data yang akan diperoleh adalah:

a. Sejarah SMP Muhammadiyah Karangasem Bali dan perkembangannya

b. Foto-foto dokumen yang terkait dengan pembelajaran PAI di Sekolah SMP Muhammadiyah Karangasem Bali.

c. Data-data sekolah SMP Muhammadiyah Karangasem Bali yang berupa prestasi siswa, data guru dan karyawan, jadwal kegiatan, dan lain-lain.

\section{Paparan Data Dan Temuan Peneliti}

Berikut ini akan dipaparkan data yang didapatkan berdasarkan hasil observasi, wawancara, dan dokumentasi di SMP Muhammadiyah Karangasem Bali:

\section{Upaya Guru PAI dalam Membentuk Karakter Religius Melalui Kegiatan Keagamaan}

Dari hasil observasi pada tanggal 25 April 2015, kegiatan keagamaan SMP Muhammadiyah Karangasem Bali sudah dikatakan berjalan dinamis atau seimbang, karena dilihat dari proses pelaksanaan kegiatan keagamaan peserta didik melaksanakannya dengan tertib, bahkan dengan tenang. Adapun kegiatan keagamaan yang dilakukan yaitu shalat Dhuha, membaca surah Al Waqi'ah, shalat Dzuhur berjamaah, dan ekstrakurikuler keagamaan. Di samping itu, dengan penambahan satu jam pelajaran PAI yang digunakan untuk praktik ibadah, sharing, pembiasaan, keteladanan yang diterapkan oleh guru untuk memacu siswa dalam meningkatkan kualitas ibadah siswa. $^{12}$

Hal tersebut sesuai dengan pendapat Guru PAI, bahwa Upaya Guru PAI dalam Membentuk Karakter Religius Melalui

${ }^{11}$ W. Gulo, Metodologi Penelitian. (Jakarta: PT Grafindo, 2004), h. 23

${ }^{12}$ Observasi di SMP Muhammadiyah Karangasem Bali, 25 April 2015. 
Kegiatan Keagamaan di SMP Muhammadiyah Karangasem Bali.

Pertama, mengupayakan shalat dhuha yang dilaksanakan satu minggu sekali perkelas, dan untuk kelas tiga melaksanakan dua kali seminggu.

Kedua, membaca surat al-waqi'ah dan do'a yang dilaksanakan setelah shalat dhuha yang dibimbing oleh wali kelas.

Ketiga, sholat berjamaah merupakan bentuk ibadah yang sangat kental dengan nila-nilai kebersamaan.

Keempat, penambahan jam pelajaran PAI 1 jam.

Berdasarkan wawancara dengan Kepala Sekolah Bapak Maflur Suhaidi S.Ag beliau menuturkan tentang upaya guru PAI dalam membentuk karakter religius yaitu :

"Adapun pembentukan karakter religius melalui kegiatan keagamaan di SMP Muhammadiyah Karangasem Bali yaitu dengan metode keteladanan dan pembiasaan. Metode keteladanan meliputi dengan mengupayakan pemaksimalan sholat berjamaah Dhuha dan Dzuhur, dan pembacaan al-qur'an dan adapun pembentukan lainnya yakni pembiyasaan berjabat tangan setiap pagi dan mengucapkan salam pada warga sekolah. ${ }^{13}$

Berikut juga wawancara dengan Bapak Budiman S.Pd.i selaku Guru PAI tentang upaya dan metode yang digunakan dalam pembelajaran dalam membentuk karakter religius di SMP Muhammadiyah Karangasem Bali :

"Guru Pendidikan Agama Islam merupakan tenaga yang sangat bertanggung jawab terhadap pembinaan watak, kepribadian, keimanan, ketakwaan, dan karakter peserta didik. Sebagai guru pendidikan agama Islam, berbagai upaya yang dilakukan dalam membentuk karakter religius melalui kegiatan keagamaan,

${ }^{13}$ Wawancara dengan Kepala Sekolah SMP Muhammadiyah Karangasem Bali, 26 April 2015. 
seperti dalam pembelajaran PAI sangat menekankan pada kegiatan-kegiatan ibadah misalnya praktik shalat wajib, shalat Jum'at, membaca Al Qur'an, dzikir, adzan, dan iqamah untuk mengingatkan siswa supaya memperbaiki shalatnya yang belum sempurna. Hal ini merupakan bekal kepada siswa pada kehidupan kelak. Di samping itu, guru harus memberikan keteladanan kepada peserta didik agar peserta didik meniru seperti mengajak shalat Dhuha berjamaah, Dzuhur berjamaah, dan lain-lain". ${ }^{14}$

Dengan pemaparan di atas, bagaimana upaya guru PAI dalam membentuk karakter religius melalui pembelajaran PAI yang diajarkan tidak hanya ranah kognitif saja, melainkan juga afektif dan psikomotorik, yaitu mempraktikkan langsung dan menghayati. Di samping itu, berbagai keteladanan yang diterapkan dalam membentuk karakter yang religius seperti shalat Dhuha berjamaah, membaca surah Al Waqi'ah, shalat Dzuhur berjamaah, dan lain-lain. Guru-guru selalu mengawasi dan ikut melaksanakan kegiatan keagamaan.

Sebagaimana hasil wawancara dengan Waka Kurikulum Bapak Andy Shopia, Spd tentang upaya pembentukan karakter melalui kegiatan-kegiatan keagamaan.

"Pengaruhnya sangat besar sekali terhadap karakter peserta didik, karena dilihat dari latar belakang siswa kebanyakan orang tua siswa kurang peduli terhadap hal ibadah. Sehingga di lembaga SMP Muhammadiyah Karangasem Bali mengupayakan pemaksimalan shalat berjamaah Dhuha, Dzuhur, dan semua guru mendukung upaya tersebut. Jadi guru-guru ikut melaksanakan dan mengawasi dalam melaksanakan kegiatan tersebut". 15

Pembentukan karakter melalui kegiatan keagamaan guru PAI tidak berjalan sendiri, kepala sekolah dan semua guru ikut serta

\footnotetext{
${ }^{14}$ Wawancara dengan Guru PAI SMP Muhammadiyah Karangasem Bali, 28 April 2015.

${ }^{15}$ Wawancara dengan Waka. Kurikulum SMP Muhammadiyah Karangasem Bali, 29

April 2015.
} 
dalam pelaksanaan kegiatan keagamaan, meskipun tanggung jawab kegiatan ada pada guru agama. Seperti pada shalat Dzuhur berjamaah giliran menjadi imam semua guru sesuai dengan jadwal yang sudah ditetapkan. Dengan adanya kegiatankegiatan keagamaan di SMP Muhammadiyah Karangasem Bali siswa menjadi terbiasa melaksanakannya sendiri dirumah.

Sebagaimana pernyataan dari siswa SMP Muhammadiyah Karangasem Bali terkait dengan pembentukan karakter melalui kegiatan keagamaan.

"Dengan adanya berbagai kegiatan keagamaan seperti shalat jamaah, Saya senang sekali karena menjadi terbiasa dan ketika di rumah pun juga melaksanakannya. Dan di samping itu, guru PAI yang menyenangkan dalam mengajar, sehingga Saya tidak malu bertanya tentang keagamaan". ${ }^{16}$

2. Faktor Pendukung dan Penghambat Pembentukan Karakter Religius Melalui Kegiatan Keagamaan

Dari apa yang kami teliti terhadap faktor pendukung dan faktor penghambat kegiatan keagamaan di SMP Muhammadiyah Karangasem Bali, adalah sebagai berikut:

\section{a. Faktor Pendukung}

Adapun faktor yang mendukung dalam pembentukan karakter religius melalui kegiatan keagamaan adalah:

1. Adanya fasilitas ibadah, sehingga kegiatan keagamaan tidak hanya dilakukan dikelas, melainkan pembelajaran PAI dilakukan di ruang ibadah atau Musholla yang telah disediakan

2. Adanya kekompakkan dari dewan guru dalam mengawasi, membimbing, dan mengarahkan. Disamping itu dewan guru juga ikut melaksanakan kegiatan keagamaan

${ }^{16}$ Wawancara dengan Muhammad Shadiq siswa SMP Muhammadiyah Karangasem Bali, 29 April 2015. 
3. Adanya pelaksanaan shalat jum'at keliling bagi bapak guru, hal ini dilakukan sembari untuk mengadakan pertemuan dengan walimurid, yang mana hal tersebut bertujuan untuk membicarakan aktivitas dan perkembangan belajar dan akhlak siswa

\section{b. Faktor Penghambat}

Hal tersebut berdasarkan hasil wawancara bersama guru PAI Bapak Budiman S.PdI, adapun faktor penghambat dalam membentuk karakter religius melalui kegiatan keagamaan, sebagai berikut:

Faktor penghambat pembentukan karakter antara lain:

1. Faktor pergaulan anak didik itu sendiri, artinya dalam pergaulan anak didik biasanya memperoleh pengaruh dari lingkungan, sehingga hal ini akan menghambat pembentukan karakter peserta didik.

2. Kurangnya perhatian dan pengawasan orang tua terhadap hal ibadah.

\section{Hasil Pembentukan Karakter Religius Melalui Kegiatan Keagamaan}

Berdasarkan wawancara dengan Bapak Budiman, S.Pd.I selaku guru PAI tentang hasil pembentukan karakter religius melalui kegiatan keagamaan.

"Setelah melakukan pembinaan karakter religius melalui kegiatan keagamaan siswa dapat berakhlakul karimah, siswa melaksanakan shlat secara kompak, tidak gaduh mudah diatur, dan siswa melaksanakan secara tepat". ${ }^{17}$

Dari pemaparan di atas, sangat jelas bahwa seorang guru PAI bertujuan untuk membentuk karakter yang religius dalam bentuk pengetahuan, pembiasaan, dan keteladanan untuk memupuk peserta didik menjadi seorang yang mempunyai sosok tersendiri dalam hidupnya atau bahkan menjadi manusia yang kamil dalam

${ }^{17}$ Wawancara Dengan Guru PAI SMP Muhammadiyah Karangasem Bali Pada Tanggal 29 April 2015 
berakhlak, sehingga anak-anak di SMP Muhammadiyah memiliki kesadaran dalam menjalankan perintah Allah.

\section{Pembahasan}

Pada pembahasan ini berisi analisis data atau penafsiran yang ditemukan berdasarkan konseptual yang telah dipaparkan pada bab II tentang Upaya Guru PAI dalam Membentuk Karakter Religius melalui Kegiatan Keagamaan di SMP Muhammadiyah Karangasem Bali.

\section{Upaya Guru PAI dalam Membentuk Karakter Religius melalui Kegiatan Keagamaan di SMP Muhammadiyah Karangasem Bali}

Menurut hasil interview dengan berbagai pihak di SMP Muhammadiyah Karangasem Bali, Penulis dapat menganalisis bahwa guru Pendidikan Agama Islam harus memiliki komitmen yang sangat tinggi dalam mencerdaskan serta mengembangkan pendidikan, utamanya dalam membentuk karakter. Hal ini dibuktikan dengan adanya berbagai macam usaha yang dilakukan dalam membentuk karakter religius yaitu shalat Dhuha, membaca surah Al Waqi'ah, shalat Dzuhur berjamaah, dan penambahan satu jam pelajaran PAI yang digunakan untuk praktik ibadah, pembinaan tentang keagamaan, pembiasaan, dan keteladanan yang diterapkan oleh guru, sehingga peserta didik dapat meniru atau meneladani dan lain sebagainya. Hal ini sesuai dengan apa yang dikatakan Abdul Majid dalam buku Belajar dan Pembelajaran Agama Islam.

Oleh karena itu, upaya guru PAI dalam membentuk karakter religius melalui pembelajaran PAI tidak hanya sebatas mentransfer ilmu saja, namun lebih jauh dari pengertian itu, yang lebih utama adalah dapat mengubah atau membentuk karakter dan watak seseorang agar menjadi lebih baik, lebih sopan dalam etika, estetika, maupun perilaku dalam kehidupan sehari-hari. 
2. Faktor Pendukung dan Penghambat Guru PAI dalam Membentuk Karakter Religius melalui Kegiatan Keagamaan di SMP Muhammadiyah Karangasem Bali

Menurut hasil interview dengan guru PAI, faktor-faktor pendukung dan penghambat pembentukan karakter religius melalui kegiatan keagamaan adalah sebagai berikut: faktor pendukung adanya fasilitas ibadah atau mushalla, kekompakkan dewan guru dalam membimbing, mengawasi dan mengarahkan, adanya pelaksanaan jum'at keliling bagi bapak guru untuk mengadakan pertemuan dengan wali murid yang mana bertujuan untuk membicarakan aktivitas dan perkembangan belajar dan akhlak siswa. Sedangkan faktor penghambat yaitu factor pergaulan anak didik itu sendiri, artinya dalam pergaulan anak didik biasanya memperoleh pengaruh dari linkungan sehingga hal ini akan menghambat pembentukan karakter peserta didik, serta kurangnya perhatian dan pengawasan orangtua terhadap hal ibadah.

Hal ini sesuai dengan apa yang dikatakan oleh Pupuh Fathurrahman dalam buku Pengembangan Karakter bahwa: Keluarga adalah faktor genetika yang mempunyai peranan penting dalam perkembangan dan pematangan kepribadian. Peran dan sikap orang tua mempunyai dampak yang signifikan untuk menentukan kepribadian si anak. Hal ini yang serupa pernah disinggung Rasulullah saw bahwasanya asal anak adalah fitrah, tergantung orang tuanya yang menjadikan dia seperti apa, kafir, Islam, penurut, pendiam, dan lain sebagainya.

Inteligensi atau kecerdasan erat hubungannya dengan pikiran, yang dalam konteks pengaruhnya terhadap perkembangan kepribadian sangat menentukan pula (di samping genetik) dengan cara melihat dampak dari aktivitas pikiran seseorang itu sendiri.

Teman sebaya memiliki pengaruh sangat besar pada kehidupan seseorang. Teman yang berkepribadian buruk akan menularkan hal-hal yang negatif kepada teman sepergaulannya. 
Banyak sekali pemuda yang mengalami penyimpangan perilaku dan terjerumus dalam perbuatan hina karena terpengaruh oleh temannya. Teman yang buruk memiliki andil besar dalam menjerumuskan seseorang ke dalam keburukan. Penting sekali memilih teman yang berkepribadian mulia dan begitu pula sebaliknya. Menjauhi teman yang berkepribadian buruk juga amat penting. Karena Rasulullah saw sendiri telah mengisyaratkan dengan berwasiat agar seseorang memilih teman yang shalih dan menghindari teman yang buruk.

Kebudayaan atau lingkungan dan perkembangan kepribadian seseorang sangat dipengaruhi oleh kondisi lingkungan sosial budaya setempat, tradisi, nilai-nilai, perilaku kedua orang tua, cara orang tua mendidik dan memperlakukannya, berbagai macam media, serta berbagai macam peristiwa yang dialami dalam kehidupannya. Dalam masa adaptasinya, anak atau bahkan manusia dewasa akan mempelajari bahasa yang digunakan sebagai alat komunikasi dalam kehidupannya, mempelajari agama yang diyakini orang tuanya, dan mempelajari kepribadian, kecenderungan, serta pemikiran.

\section{Hasil Pembentukan Karakter Religius Melalui Kegiatan} Keagamaan

Berdasarkan hasil wawancara dengan Bapak Budiman, S.Pd.I selaku guru PAI yaitu "Setelah melakukan pembinaan karakter religius siswa SMP Muhammadiyah Karangasem Bali , siswa dapat berakhlakul karimah, melakukan shalat secara tepat waktu, siswa melaksanakan shalat secara kompak, tidak gaduh, mudah diatur dan siswa melaksanakan shlat secara tepat.

Hal ini sesuai dengan apa yang dikatakan oleh Imam Suprayogo dalam buku Pengembangan Pendidikan Karakter bahwa Islam memberikan tuntunan tentang bagaimana kegiatan ritual seharusnya dilakukan oleh setiap muslim. Kegiatan ritual yang dimaksud itu seperti berdzikir, shalat, puasa, haji, dan lain-lain. Kegiatan itu sangat penting untuk membangun 
kekuatan spiritual bagi mereka yang menjalankan. Melalui kegiatan spiritual itu, maka terbangun komunikasi antara manusia dengan Dzat Yang Maha Pencipta. Dengan kegiatan spiritual itu pula maka terbangun sikap mulai seperti rendah hati, sabar, ikhlas, amanat, peduli sesama, saling mencintai, dan lain-lain.

Dengan demikian, agar Islam menjadi kekuatan untuk membangun karakter bangsa secara utuh, maka ajaran yang dibawa harus dipahami secara utuh pula. Maka guru Pendidikan Agama Islam harus membimbing, mengarahkan, dan memberikan keteladanan serta pengawasan sehingga peserta didik memahami pendidikan agama secara mendalam, karena dengan pengetahuan agama secara mendalam akan terbentuk jiwa-jiwa yang religius.

\section{E. Kesimpulan}

Berdasarkan penelitian yang dilakukan dalam rangka penyusunan skripsi yang berjudul "Upaya Guru PAI dalam Membentuk Karakter Religius Melalui Kegiatan Keagamaan di SMP Muhammadiyah Karangasem Bali”, maka dapat disimpulkan sebagai berikut:

1. Upaya guru PAI dalam membentuk karakter religius melalui kegiatan keagamaan di SMP Muhammadiyah Karangasem Bali yaitu shalat Dhuha, membaca surah Al Waqi'ah, shalat Dzuhur berjamaah, dan dengan adanya penambahan satu jam pelajaran PAI yang digunakan untuk praktik ibadah, bimbingan, pembinaan kegiatan keagamaan dan keteladanan yang diterapkan oleh guru PAI untuk memacu siswa dalam meningkatkan kualitas ibadah.

2. Faktor-faktor yang mendukung guru PAI dalam membentuk karakter religius melalui kegiatan keagamaan yaitu adanya fasilitas ibadah atau mushalla, dan kekompakan dari dewan guru dalam mengawasi, membimbing, dan mengarahkan. Dan adanya pelaksanaan shalat jum'at keliling bagi Bapak Guru, hal ini dilakukan sembari untuk mengadakan pertemuan 
dengan wali murid untuk membicarakan aktivitas belajar dan akhlak siswa. Sedangkan faktor yang menghambat guru PAI dalam membentuk karakter religius melalui kegiatan keagamaan yaitu, factor pergaulan anak didik itu sendiri, artinya dalam pergaulan anak didik biasanya memperoleh pengaruh dari lingkungan, sehingga hal iniakan menghambat pembentukan karakter peserta didik, kurangnya perhatian orang tua khususnya dalam hal ibadah.

3. Hasil pembentukan karakter religius melalui kegiatan keagamaan yaitu siswa dapat berakhlakul karimah, siswa dapat melaksanakan shalat secara kompak, tidak gaduh, mudah diatur dan siswa melaksanakan shalat secara tepat. 
Upaya Guru PAI dalam Membentuk Karakter Religius melalui Kegiatan

Keagamaan di SMP Muhammadiyah Karang Asem Bali

\section{DAFTAR PUSTAKA}

Cik Hasan Basri Ms, 1998, Penuntun Penyusunan Penelitian dan Penulisan Rencana Skripsi. (Jakarta: PT Logo Wacana Ilmu)

Lexy J. Meleong, 2014, Metode Penelitian Kualitatif, (Bandung:

PT. Remaja Rosda karya)

Nana Syaodih Sukmadinata, 2010, Metode Penelitian Pendidikan,

( Bandung: PT Remaja Rosda Karya)

Nusa Putra dan Nanin Dwi Lastri, 2012, Penelitian Kualitatif

PAUD, (Jakarta: PT. Raja Grafindo Persada)

Pupuh Fathurrohman, dkk, 2013, Pengembangan Pendidikan

Karakter, (Bandung: PT Refika Aditama)

S. Margono, 1997, Metodologi Penelitian Pendidikan. (Jakarta :

PT. Rineka Cipta)

Thomas Lickona, 2013, Educating For Character: Mendidik

Untuk Membentuk Karakter, (Jakarta: PT Bumi Aksara)

W. Gulo, 2004, Metodologi Penelitian. (Jakarta: PT Grafindo)

Wijaya Kusuma dan Dadi Dwitajama, 2009, Mengenal Penelitian

Tindakan Kelas, (Jakarta : Indeks)

Zakiah Daradjat, 1992, Ilmu Jiwa Agama, (Jakarta: Bumi Aksara) 